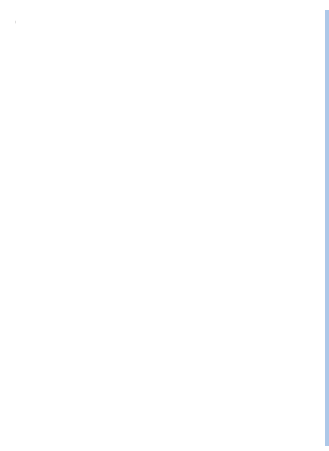

Journal of Geology,

ISSN 2617-2909 (print)

Geography and

Geoecology

ISSN 2617-2119 (online)

Journ. Geol. Geograph.

Geology,

30(4), 706-717.

Journal home page: geology-dnu.dp.ua

doi: $10.15421 / 112165$

Poongodi R ., Venkateswaran S., Suresh R.,Vimala R.

Journ. Geol. Geograph. Geoecology, 30(4), 706-717

\title{
Appraisal of the Quality Parameters of the Groundwater used for Domestic and Irrigation Purposes in the Hard Rock Aquifer System of the Vasishta sub- basin of the Vellar River, Tamil Nadu
}

\author{
Poongodi R ., Venkateswaran S., Suresh R., Vimala R. \\ Periyar University, Salem, Tamil Nadu, India Govt. Arts College for Women, Salem, Tamil Nadu, India, \\ poovijigeo@gmail.com,geosvenkat@gmail.com
}

\section{Received: 02.12.2020 \\ Received in revised form: 15.07 .2021 \\ Accepted: 25.10.2021}

\begin{abstract}
This article presents an appraisal of the quality of groundwater in the hard rock aquifer system of the Vasishta sub basin, of the Vellar River Basin. Seventy nine representative groundwater samples were collected from dug and bore wells which are intensively used for domestic and irrigational purposes. The physical parameters viz. $\mathrm{P}^{\mathrm{H}}$,
\end{abstract} EC and TDS were estimated in the field using a portable multiparameter meter. The groundwater samples were transported to the laboratory for measuring major ionic concentrations viz, $\mathrm{Ca}, \mathrm{Mg}, \mathrm{Na}, \mathrm{K}, \mathrm{CO}_{3}, \mathrm{HCO}_{3}, \mathrm{Cl}, \mathrm{SO} 4, \mathrm{~F}$ and $\mathrm{NO}_{3}$. The hydrochemical data were graphically projected and spatial temporal thematic maps generated with reference to the World Health Organization (WHO) and Bureau of Indian (BIS) Standards. The peoples living in the sub basin engage in agricultural activities where the groundwater availability is sufficient. The groundwater is a major source for meeting their basic needs, such as for domestic, irrigational and industrial purposes. Good correlation is exhibited between $\mathrm{EC}$ and $\mathrm{TDS} \mathrm{Cl}, \mathrm{SO}_{4}$. Cl exhibits good correlation with $\mathrm{Mg}$ and $\mathrm{Ca}(0.817)$, (0.751) indicating leaching of secondary salts. TDS and EC showed strong correlation with $\mathrm{Cl}, \mathrm{SO}_{4}$. Clustering groundwater samples based on their similarity is known as Q-mode type clustering method. Spatial and temporal maps of the water quality index reveal that the majority of the groundwater samples fall under the categories excellent to good.

Keywords: groundwater quality, Vasishta sub basin, domestic and irrigational purposes, multiparameter, major ionic concentration, WHO and BIS Standard, Correlation matrix.

\section{Оцінка параметрів якості підземних вод для побутових та іригаційних цілей у системі водоносних горизонтів твердих порід (Хард рок) суббасейну Васишта, річка Веллар Таміл Наду}

\author{
Пунгоді Р., Венкатесваран С., Сюреш Р., Вімала Р. \\ Періярський університет, Салем, Таміл Наду, Індія, poovijigeo@gmail.com, geosvenkat@gmail.com
}

\begin{abstract}
Анотація. Для даного дослідження було розглянуто оцінку якості підземних вод у системі водоносного шару твердих порід суббасейну Васишта, річка Веллар. Сімдесят дев'ять проб підземних вод були зібрані з викопаних і бурових свердловин, які інтенсивно використовуються для побутових і іригаційних цілей. Фізичні параметри: PH, EC та TDS, оцінені в польових умовах за допомогою портативного мультипараметра. Зразки підземних вод транспортували до лабораторії для оцінки основних концентрацій іонів, зокрема $\mathrm{Ca}, \mathrm{Mg}, \mathrm{Na}, \mathrm{K}, \mathrm{CO}_{3}, \mathrm{HCO}_{3}, \mathrm{Cl}, \mathrm{SO}_{4}, \mathrm{~F}$ та $\mathrm{NO}_{3}$. Результати гідрохімічних досілджень графічно спроектовані та просторово-часові тематичні карти, сформовані 3 посиланням на Світову організацію охорони здоров’я (BOO3) та Бюро індійських стандартів (BIS). Люди, які живуть у підбасейні, займаються сільським господарством там, де достатньо підземних вод, підземні води $є$ основним джерелом для задоволення основних потреб, таких як побутові, зрошувальні та промислові. Хороша кореляція виявляється між $\mathrm{EC}$ та TDS, $\mathrm{Cl}, \mathrm{SO}_{4}$. $\mathrm{Cl}$ демонструє хорошу кореляцію $3 \mathrm{Mg}$ та Са $(0,817),(0,751)$, що свідчить про вимивання вторинних солей. TDS та ЕС показали сильну кореляцію з $\mathrm{Cl}_{1} \mathrm{SO}_{4}$. Кластеризація зразків підземних вод на основі їх подібності відома як метод кластеризації типу Q-mode. Просторові часові карти індексу якості води показують, що більшість проб підземних вод підпадають під категорії від відмінної до хорошої.
\end{abstract}

Ключові слова: якість підземних вод, суббасейн Васишта, побутові та іригаційні иілі, мульти параметр, основна іонна кониентрачія, стандарт ВООЗ та Бюро індійських стандартів, корелячійна матриия.

\section{Introduction.}

Water is often considered to be one of the most important resources of our planet. It is the most abundant physical substance and transparent liquid on the earth.
Groundwater is the largest obtainable resource for fresh water. Ground water is commonly referred as water which lies below the surface of the earth occupying the interstices and voids in various formations (Todd, 
1980).It is the major readily available source of fresh water on our earth (Ragunath, 1987). Nowadays ground water resources are being continuously exploited from the aquifers to meet industrial, agricultural and domestic needs. Rapid urbanization, industrialization, frequent failures in the monsoon and reduced surface water resources have created a major threat to the groundwater resource in terms of quantity and quality.Groundwater is always an underwater movement and the flow takes place from the higher potentiometric surface to the lower potentiometric surface. Groundwater geochemistry is a forensic tool which helps to understand the possible processes that control groundwater chemistry as well as helping with planning for efficient water management (Subramani et al. 2010). Therefore chemical fluxes in groundwater environment indicate the dynamic movement and prolonged hydrochemical interactions (Bernard et al. 2006). Sreedevi et al. (2001) have used the remote sensing and GIS techniques to understand the occurrence of groundwater in various geomorphological units of the study area. Water resources play a vital role in the growth and development of human civilization on the surface of the earth and play a key role in the economy of any country. Ground water resources in the Vasishta sub-basin, Tamil Nadu, India are being continuously exploited to meet the demand for the water supply and irrigation because the water available in surface water bodies such as wells, tanks and reservoirs is not sufficient, and thus the resulting rapid decline in the ground water head in many areas. Groundwater quality is also affected in many places of the sub-basin due to anthropogenic activities. In hard rock terrain with arid and semi-arid climatic conditions, all the water requirements are met by sub-surface water due to reduction in surface water resources. Changing climatic conditions, growing population, industrialization, and intensive agricultural and urbanization activities have led to a high demand for groundwater especially in countries experiencing economic growth like India (Srinivasamoorthy et al. 2011). However, no systematic work has been carried out in this sub-basin to understand the ground water regime. Thus, it is essential to assess the ground water quality for extraction and management of the water resources, which is emerging as a great public concern in this region.

Study Area.The Vasishta sub- basin of the Vellar River Basin, in Tamilnadu covers in total an area of $1770.78 \mathrm{~km}^{2}$. The Vasishta is a major stream river originating from the southern slope of the Kalrayan Hills and flows through Kurichi, Belur, Pethanaikenpalaiyam, Attur, Thalaivasal and Aragalur, habitations of Salem and Perambalur districts of Tamilnadu. Major and minor artificial recharge structures, constructed across the streams significantly contribute to groundwater recharge in the sub basin. Irrigation mainly depends upon the groundwater resources from dug and bore wells. Groundwater is the main source of water for agricultural activities and is pumped through dug and bore wells. (Poongodi and Venkateswarn 2018). The important plants cultivated are finger millet, jasmine, cucumbers, maize, groundnuts, celosia, betel trees, tapioca tubers, cotton grass, sugar cane, turmeric, coconuts, bananas and areca nut.The base map of the study area is given in Fig.1

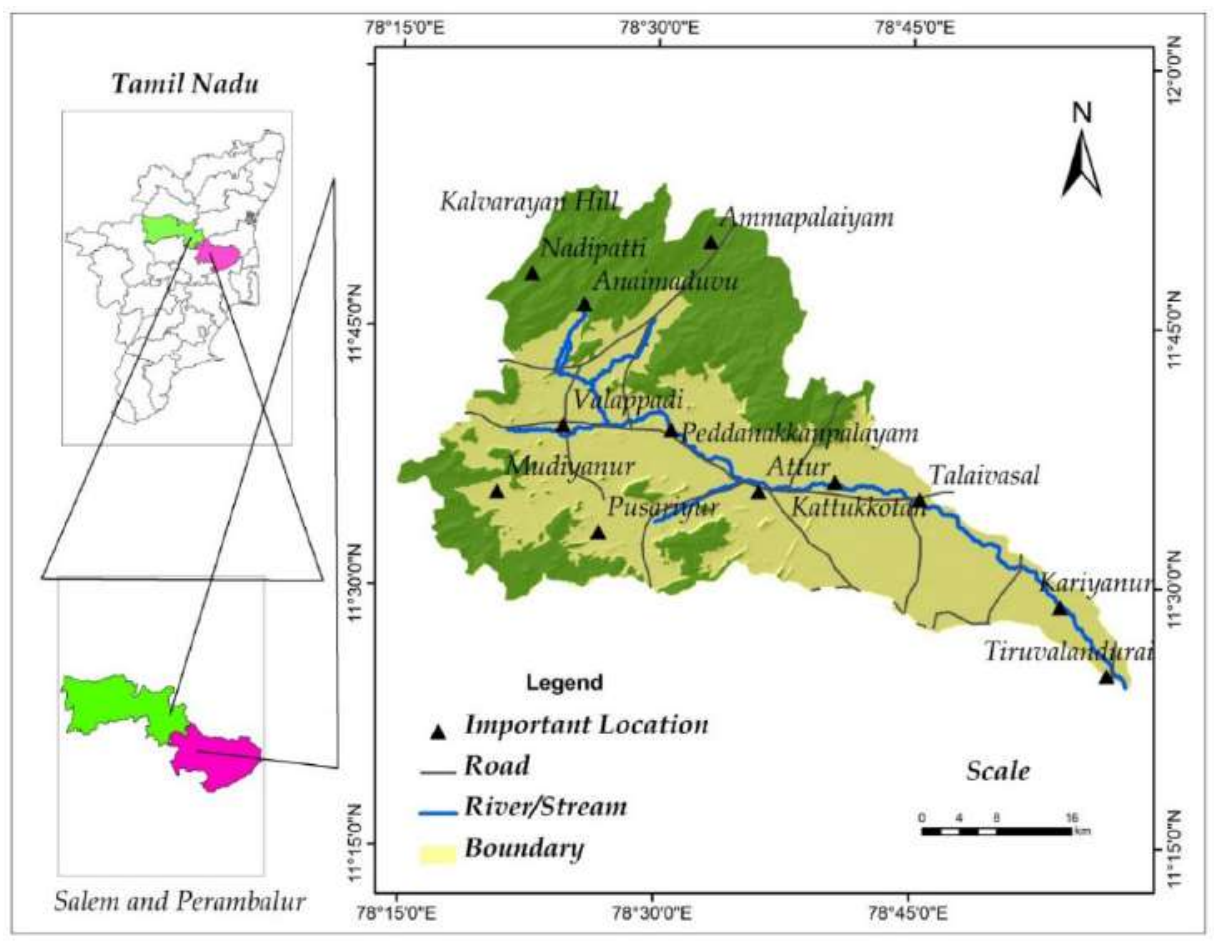

Fig.1. Base map of the Vasishta sub basin 
Geology and hydrogeological settings. The Vasistha sub- basin is mainly underlain by crystalline rocks of Archean age, of gneissic rocks, charnockite, pyroxenite, amphibole pyroxene granulite and mylonite respectively. The geomorphological units are structural hills and pediplain denudation hillspediments and floodplain. The structural hill is located in the northwestern parts of the study area whereas the southwestern and eastern parts of the study area are occupied by gently undulating and dotted relic isolated hillocks underlain by a hard rock crystalline aquifers system and groundwater phreatic condition. The occurrence and movements of groundwater through weathered zones is followed by occurrence of fissures, joints and fractures, The availability of groundwater in the sub- basin is greater in the river courses of paleochannels, foothills of the Kalrayan Hills, Bothumalai, and Sitheri Hills.

\section{Materials and Methods.}

A total of 79 groundwater samples was systematically collected from sources intensively utilized by farmers. Physical parameters such as colour, odour, taste, turbidity, $\mathrm{P}^{\mathrm{H}}$ and $\mathrm{EC}$ were estimated in the field itself. The samples were sent to the laboratory for further ionic concentration analysis. The ionic concentration was estimated using titration method, spectrophotometer and flame photometer. Shown in Fig.2.

Standardization of analytical data. The hydochemical data were standardized graphically as shown in Fig. 3. It shows the total sum of cations versus the total sum of anions for groundwater samples, it also indicates all the samples on or near the aquiline in the graph. The quality of the analysis was documented by standardization using blank, spike, and duplicate water samples.

The hydrochemical data have been projected graphically using Piper's, Wilcox's, Donnen's and Gibb's plots for understanding the suitability of water for domestic irrigation and industrial purposes. A set up of spatio- temporal maps have been generated in the GIS platform with reference to the WHO and BIS Standards.

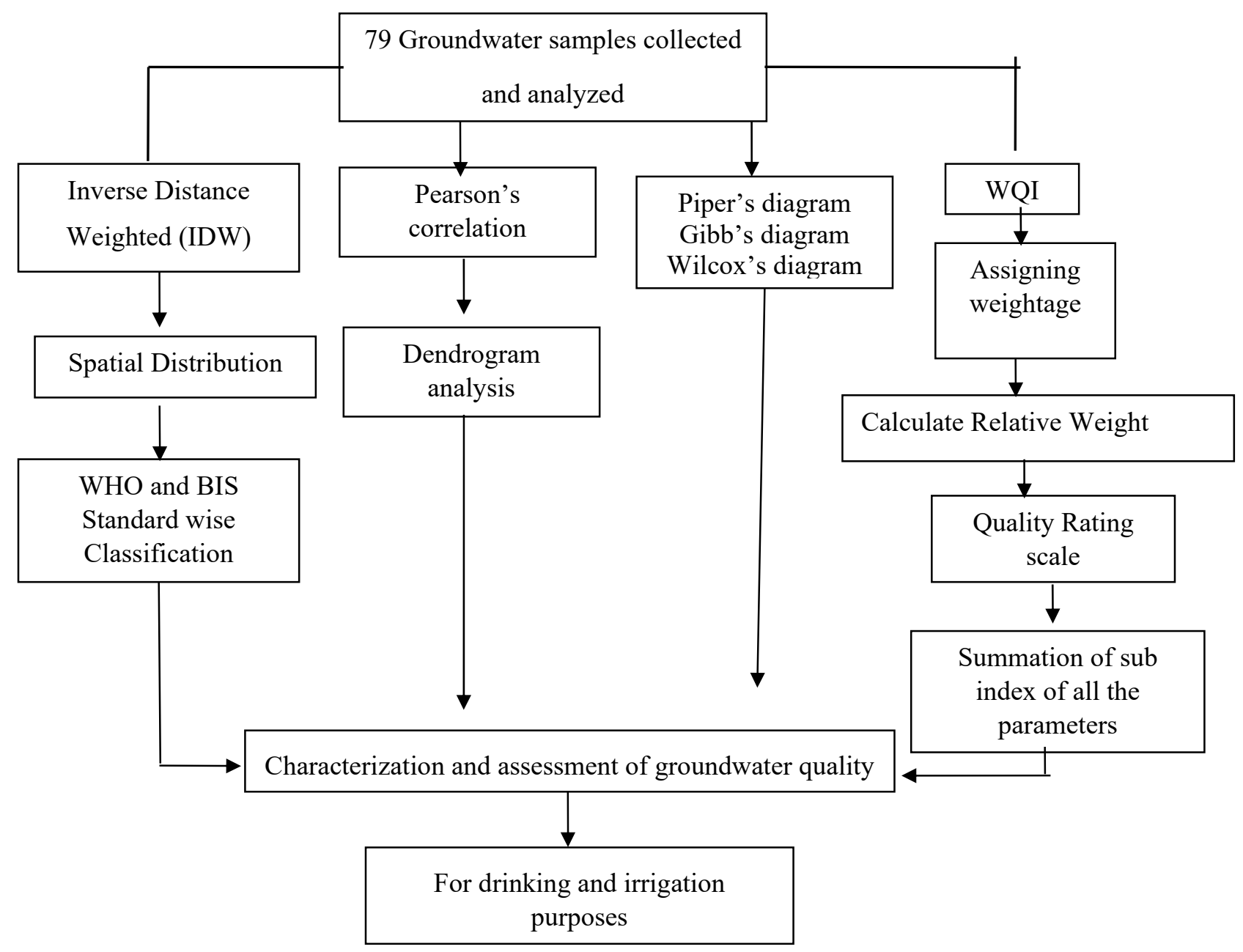

Fig. 2. Flow chart for the Methodology 


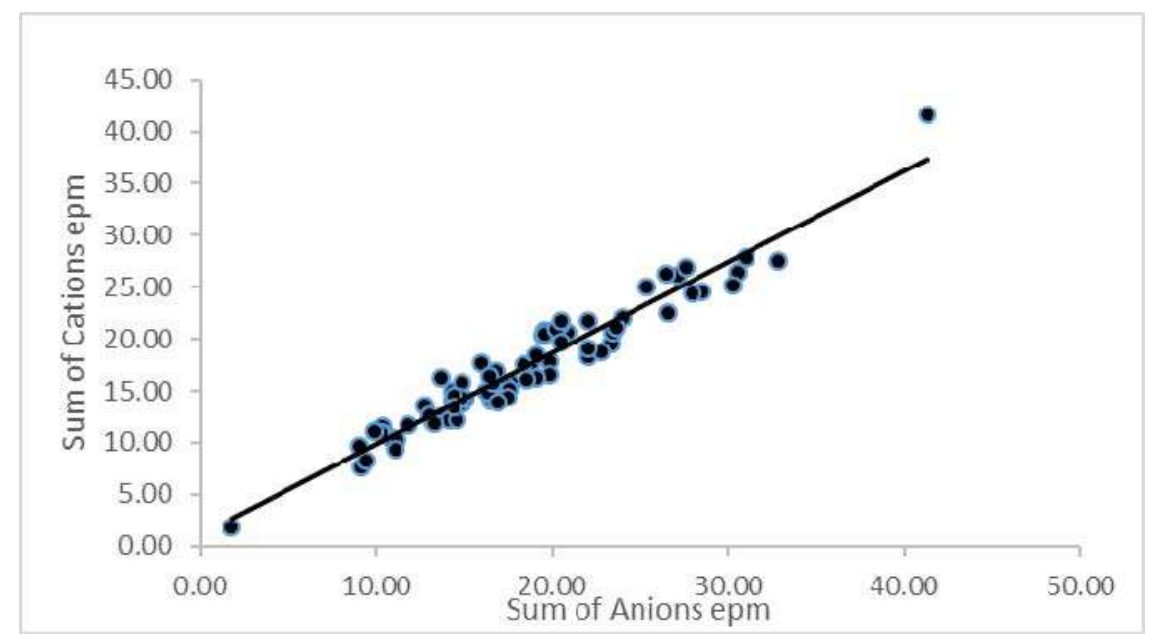

Fig. 3. Correlation co-efficient between total concentration of Cation epm and total concentration of Anion epm

\section{Result and Discussion.}

Water quality appraisal. The WHO standard was followed for the physical and chemical parameters for the groundwater samples of the study area. It was found that $\mathrm{P}^{\mathrm{H}}$ limit varies from 6.74 to 8.41 , which indicates that groundwater is acidic, alkaline, and $5 \%$ to $95 \%$ of the groundwater sample is of potable category, the $\mathrm{P}^{\mathrm{H}}$ value within the maximum falls within the permissible category. The groundwater through the quantity of transmitting electrical current. WHO limit in EC 1500 $\mu \mathrm{s} / \mathrm{cm}^{2}$, The values varied from $190 \mu \mathrm{s} / \mathrm{cm}^{2}$, to $5130 \mu \mathrm{s} /$ $\mathrm{cm}^{2}$. The high values of indicators of a huge quantity of salt occur in groundwater. 22 samples show a low amount of salt. Other samples covered high electric conductivity. TDS ranges between $373.52 \mathrm{mg} / 1$ to $4669 \mathrm{mg} / \mathrm{l}$. The TDS varied from 124 to $3335 \mathrm{mg} / 1$, which indicates rock water interaction in relation to groundwater, the TDS depending upon variation process such as domestic sewage and agricultural activities, The most common source of calcium and magnesium in groundwater concentration of $\mathrm{Ca}$ value varied from 16 to $281 \mathrm{mg} / 1.96 \%$ of the sample was of allowable category, $4 \%$ of the sample only was not of potable category, $\mathrm{Mg}$ content value varied from 7 to $153 \mathrm{mg} / \mathrm{l}$, $94 \%$ of the sample was of potable category, $6 \%$ of the sample was not of potable category. The Na values varied from $10 \mathrm{mg} / 1$ to $360 \mathrm{mg} / 1$. It values Most of the samples $(96 \%)$ were of potable category, $4 \%$ of the samples were not potable, $\mathrm{K}$ value varied from 0.5 to $43.9 \mathrm{mg} / 1.57 \%$ of the samples were of allowable category, $32 \%$ of the groundwater samples were not of potable category. WHO limit $200 \mathrm{mg} / 1$ of $\mathrm{CO}_{3} \mathrm{HCO}_{3}$, The values varied from $50 \mathrm{mg} / 1$ to $622.4 \mathrm{mg} / 1$. The chloride range was $25 \mathrm{mg} / 1$ to 1110 . The most desirable was $250 \mathrm{mg} / \mathrm{l}$. This is explained by the drainage system and polluting environments of the study area. The sulfate range was from $10 \mathrm{mg} / 1$ to $380 \mathrm{mg} / 1$. All samples were within the WHO allowable limit. Nitrogen ions contaminating subsurface endogenic activities originated in agricultural sources. The values varied from $1.5 \mathrm{mg} / \mathrm{l}$ to $18 \mathrm{mg} / \mathrm{l}$. This groundwater samples of this study area all within desirable limits. Major ions were as follows in abundance; $\mathrm{Ca}>\mathrm{K}>\mathrm{Mg}>\mathrm{Na}$ and $\mathrm{CO}_{3}>\mathrm{Cl}>\mathrm{SO}_{4}>\mathrm{HCO}_{3}>\mathrm{NO}_{3}$ respectively. Multivariate statistical analyses display good correlation. Quality of groundwater for drinking purposes based on WHO and BIS standards are given in Table.2.

Water quality Index (WQI) for domestic purposes. Water Quality Index (WQI) has been utilized as a tool to assess the spatial and temporal changes in the quality of groundwater and its appropriateness for drinking purposes, Ketata et al.(2012) and is a method using individual water quality parameters on the overall quality of the water. This calculation based on WHO standards 2011 and BIS 1991. (Vasanthivigar et al 2010,) Shown in Table 1. Its computing followed the physico- chemical parameters analysis of each of the 12 parameters, for major cations and anions

$$
W_{i}=w_{i} / \sum_{i=1}^{n} w_{i}
$$

Where, $W_{i}$ is the relative weight, $w_{i}$ is the weight of the each parameter and $\mathrm{n}$ is the number of parameter. In the second step a quality rating scale $\mathrm{q}_{\mathrm{i}}$ for the each parameter is assigned by dividing its concentration in each water sample (WHO 2011).Shown in Table 2.

$$
q_{i}=C_{i} / S_{i} \times 100
$$

Where $q_{i}$ quality rating, $C_{i}$ is the concentration of each chemical parameter in $\mathrm{mg} / \mathrm{l}$, according to WHO guidelines (2011).For computing the WQI, the sub index of its parameter (SI) is first determined for each physic- chemical parameter WQI as per the equation, Shown in Table 4. 


$$
\begin{aligned}
& \text { SI } i=W_{i} \times q_{i} \\
& \text { WQI }=\sum S I i
\end{aligned}
$$

Where, SIi is the sub index of its parameter, $\mathrm{q}_{\mathrm{i}}$ the rating based on concentration $i$ th parameter, $n$ number of the parameter.

Categorization of groundwater quality according to water quality index is as follows; $<50 \%$ Excellent water, $50 \%-100 \%$ good water, $100 \%-200 \%$ poor water, $200 \%-300 \%$ very poor water,> $300 \%$ water unsuitable for domestic purposes. The relative weight shown in Table, 1 quality rating, a total of seventy nine samples of groundwater samples was taken for water quality index in the sub- basin. Spatial distribution maps for water quality index showed $27.85 \%$ of the sample as belonging to the Excellent water category, $59.50 \%$ of the sample as belonging to the Good category and $12.65 \%$ of the sample as belonging to the Poor water category for domestic purposes respectively in the subbasin. The Water Quality Index spatial map is presented in Fig. 4

Table 1. Percentage of groundwater samples exceeding limits for drinking purposes based on WHO and BIS standard

\begin{tabular}{|c|l|c|c|c|c|c|c|c|c|}
\hline Sl.No & Parameters & Minimum & Maximum & Mean & $\begin{array}{c}\text { WHO } \\
(2011)\end{array}$ & $\begin{array}{c}\text { BIS } \\
(1991)\end{array}$ & $\begin{array}{c}\text { Desirable } \\
(\%)\end{array}$ & $\begin{array}{c}\text { Allowable } \\
(\%)\end{array}$ & $\begin{array}{c}\text { Not potable } \\
(\%)\end{array}$ \\
\hline 1 & $\mathrm{P}$ & 6.74 & 8.41 & 7.41 & $6.5-8.5$ & $6.5-8.5$ & 100 & - & - \\
\hline 2 & $\mathrm{EC}(\mu \mathrm{S} / \mathrm{cm})$ & 190 & 5130 & 2151.01 & 1500 & - & 2 & 60 & 38 \\
\hline 3 & $\mathrm{TDS}(\mathrm{mg} / \mathrm{l})$ & 124 & 3335 & 1398.42 & 500 & 500 & 2 & 64 & 34 \\
\hline 4 & $\mathrm{Ca}(\mathrm{mg} / \mathrm{l})$ & 16 & 281 & 110.53 & 75 & 75 & 18 & 78 & 4 \\
\hline 5 & $\mathrm{Mg}(\mathrm{mg} / \mathrm{l})$ & 7 & 153 & 64.76 & 50 & 30 & 38 & 56 & 6 \\
\hline 6 & $\mathrm{Na}(\mathrm{mg} / \mathrm{l})$ & 10 & 360 & 166.36 & 200 & - & 4 & - & 96 \\
\hline 7 & $\mathrm{~K}(\mathrm{mg} / \mathrm{l})$ & 0.5 & 43.9 & 10.40 & 12 & - & 62 & 6 & 32 \\
\hline 8 & $\mathrm{HCO}(\mathrm{mg} / \mathrm{l})$ & 50 & 622.404 & 336.1 & 500 & - & 11 & 89 & - \\
\hline 9 & $\mathrm{Cl}(\mathrm{mg} / \mathrm{l})$ & 25 & 1110 & 298.74 & 250 & 250 & 66 & 32 & 2 \\
\hline 10 & $\mathrm{~F}(\mathrm{mg} / \mathrm{l})$ & 0.2 & 1.9 & 0.89 & 1.5 & 1.5 & 61 & 30 & 9 \\
\hline 11 & $\mathrm{SO}_{4}(\mathrm{mg} / \mathrm{l})$ & 10 & 380 & 132.44 & 250 & 200 & 87.34 & 12.66 & - \\
\hline 12 & $\mathrm{NO}_{3}(\mathrm{mg} / \mathrm{l})$ & 1.5 & 18 & 9.93 & 45 & 45 & 100 & - & - \\
\hline
\end{tabular}

Table 2. Relative weightage of the chemical parameter for water quality index

\begin{tabular}{|c|c|c|c|c|}
\hline Sl.No & $\begin{array}{c}\text { Physico- chemical } \\
\text { parameter }\end{array}$ & $\begin{array}{c}\text { WHO } \\
\text { Standers } \\
(2011)\end{array}$ & $\begin{array}{c}\text { Weightage } \\
\left(\mathrm{w}_{\mathrm{i}}\right)\end{array}$ & $\boldsymbol{w}_{\boldsymbol{i}}=\boldsymbol{w}_{\boldsymbol{i}} / \sum_{i=\mathbf{1}}^{\boldsymbol{w}_{\boldsymbol{i}}}$ \\
\hline 1 & $\mathrm{pH}$ & $6.5-8.5$ & 4 & 0.117647059 \\
\hline 2 & $\mathrm{EC}(\mu \mathrm{S} / \mathrm{cm})$ & 1500 & 3 & 0.147058824 \\
\hline 3 & $\mathrm{TDS}(\mathrm{mg} / \mathrm{l})$ & 500 & 4 & 0.117647059 \\
\hline 4 & $\mathrm{Ca}(\mathrm{mg} / \mathrm{l})$ & 75 & 2 & 0.058823529 \\
\hline 5 & $\mathrm{Mg}(\mathrm{mg} / \mathrm{l})$ & 50 & 1 & 0.029411765 \\
\hline 6 & $\mathrm{Na}(\mathrm{mg} / \mathrm{l})$ & 200 & 2 & 0.058823529 \\
\hline 7 & $\mathrm{~K}(\mathrm{mg} / \mathrm{l})$ & 12 & 2 & 0.058823529 \\
\hline 8 & $\mathrm{HCO}(\mathrm{mg} / \mathrm{l})$ & 500 & 3 & 0.088235294 \\
\hline 9 & $\mathrm{Cl}(\mathrm{mg} / \mathrm{l})$ & 250 & 3 & 0.088235294 \\
\hline 10 & $\mathrm{~F}(\mathrm{mg} / \mathrm{l})$ & 1.5 & 2 & 0.058823529 \\
\hline 11 & $\mathrm{SO}_{4}(\mathrm{mg} / \mathrm{l})$ & 250 & 3 & 0.088235294 \\
\hline 12 & $\mathrm{NO}_{3}(\mathrm{mg} / \mathrm{l})$ & 45 & 5 & 0.088235294 \\
\hline & & & $\sum w i=34$ & $\sum W i=1.00$ \\
\hline
\end{tabular}

Table 3. Water Quality Index is the groundwater sample in the Vasishta su-b basin

\begin{tabular}{|c|c|l|}
\hline Sl.No & Water Quality types & \multicolumn{1}{|c|}{ Groundwater sample No } \\
\hline 1 & Excellent water & $2,4,8,10,13,16,22,23,24,26,35,43,47,51,53,57,58,63$, \\
& & $74,77,78$ and 79 \\
\hline 2 & Good water & $1,3,5,6,7,9,11,12,14,15,17,18,19,20,21,25,29,30,31$, \\
& & $32,33,34,36,38,39,41,44,46,48,49,52,54,55,56,59,61$, \\
& & $62,64,65,67,68,69,70,72,73,75$ and 76 \\
\hline 3 & Poor water & $27,28,37,40,42,45,50,60,66$ and 71 \\
\hline
\end{tabular}




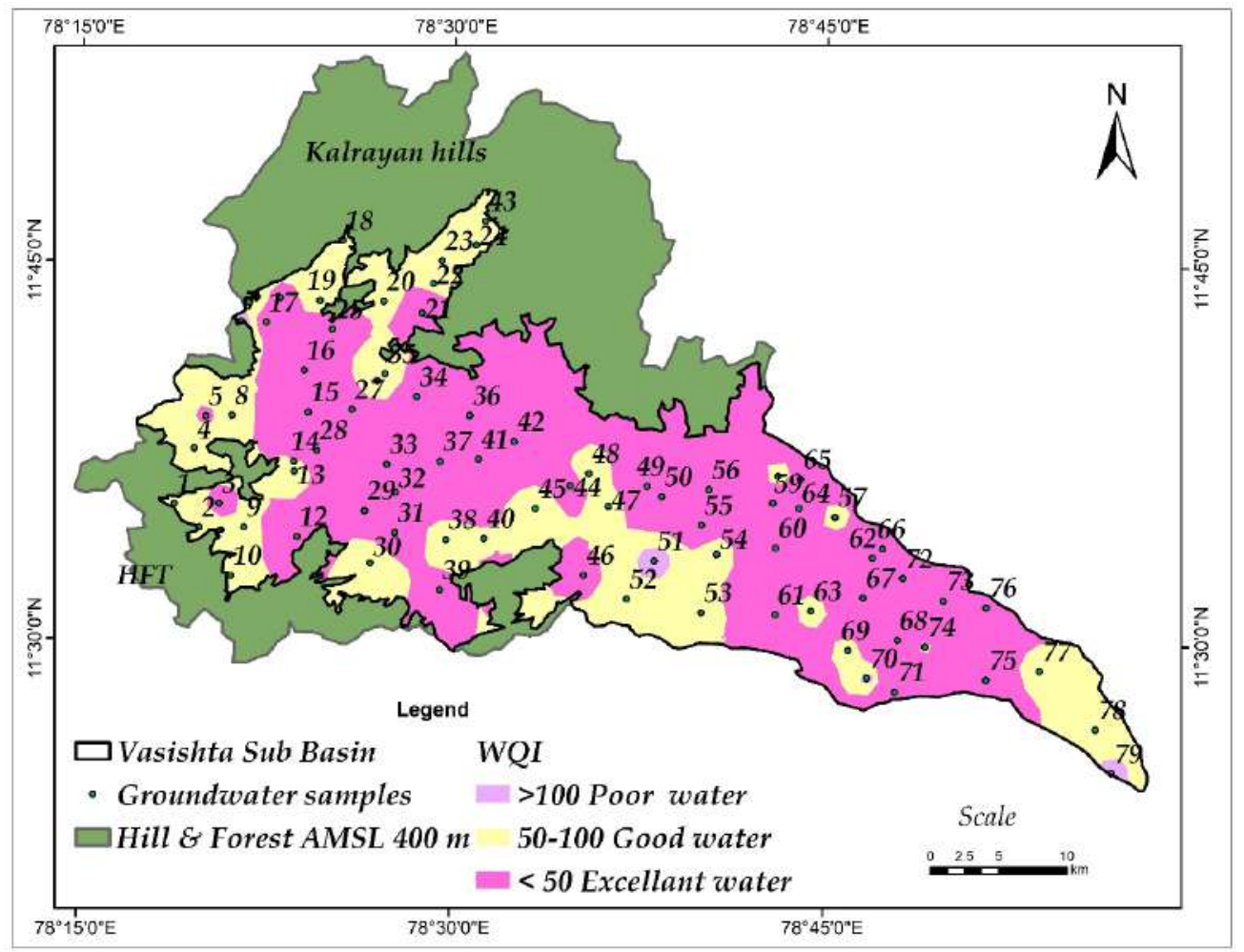

Fig. 4. Water Quality Index spatial map of the Vasishta sub- basin

Hydrogeochemical Facie. Piper's diagram (1944) includes two triangles, one for plotting cations and the other for plotting anions. The cation and anion fields are combined to show a single point in a diamond shaped field from which inferences drawn on the basis of hydrogeochemical facies concept are useful in bringing out the chemical relationship among groundwater samples in more definite terms rather than with other possible plotting methods.
The following groundwater facies have been identified in the sub basin; $\mathrm{Na}-\mathrm{K}-\mathrm{Cl}-\mathrm{SO} 4$ facies and Ca$\mathrm{Mg}-\mathrm{HCO} 3$ type, cation ions fall under domain C-sodium and potassium facies, domain A-Magnesium type, anion such as, domain E-sulphate type, F-bicarbonate type. The majority of the groundwater samples fall under $\mathrm{Ca}-\mathrm{Mg}-\mathrm{HCO} 3$ groundwater facies presented in Fig.5

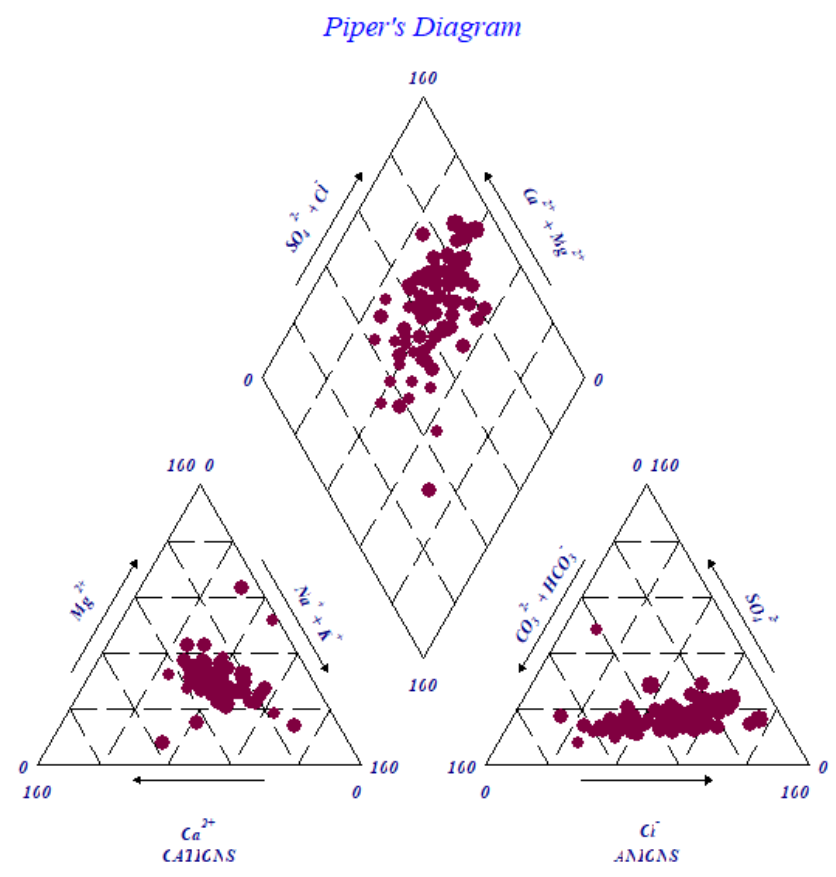

Fig. 5 Piper's hydrogeochemical facies of the Vasishta sub basin 
Groundwater and Soil relationships. The Wilcox's diagram plotted against specific conductance is used in evaluating the irrigation waters Wilcox's (1955). Sodium is one of the important ions for irrigation and agriculture purposes. Sodium is computed to relative proportions of cations present in water. Percentage of Sodium greater than $60 \%$ may result in sodium accumulations that will cause a breakdown in the soil's physical properties. Excess Na combining with carbonate leads to formation of alkali soils, whereas with chloride, saline soils are formed, and soil will not support plant growth Rao (2005). The ions' $(\mathrm{Na} \%)$ values were obtained by the following equation:

$$
\mathrm{Na} \%=\frac{\left(\mathrm{Na}+K^{\prime}\right)}{\mathrm{Ca}+\mathrm{Mg}+\mathrm{Na}+\mathrm{k}} \times 100
$$

Wilcox's Diagram is used to classify the water for irrigation, where EC plotted against $\mathrm{Na} \%$ shows that $96.21 \%$ of the groundwater samples are good to permissible and $3.79 \%$ are in the not potable category. Sodium concentration disperses soil and increasing salinity flocculates soil (Hanson et al 1999). Wilcox's plot and groundwater classifications are presented in Fig. 6 and Table 4. It is clearly stated that the water from the following villages is not of potable category; Iddaiyapatti, Vellaiyur and Thiruvalanthurai villages.

Table 4. Wilcox's groundwater classifications

\begin{tabular}{|c|c|l|}
\hline Sl.No & Water class & \multicolumn{1}{|c|}{ Groundwater sample No } \\
\hline 1 & Excellent to Good & 48 \\
\hline 2 & Good to Permissible & $1,2,4,6,8,10,11,17,13,16,19,20,21,27,28,30,33,35,37,39$, \\
& & $41,44,45,46,49,50,54,55,56,75$ and 78 \\
\hline 3 & Permissible to Unsuitable & 68 and 79 \\
\hline 4 & Doubtful to unsuitable & $7,9,12,23,29,31,32,34,36,42,47,51,52,53,59,60,62,65$, \\
& & $66,67,70,71,73,74,76$ and 77 \\
\hline 5 & Unsuitable & $43,38,64,58,15,25,2,69,35,57$ and 40 \\
\hline
\end{tabular}

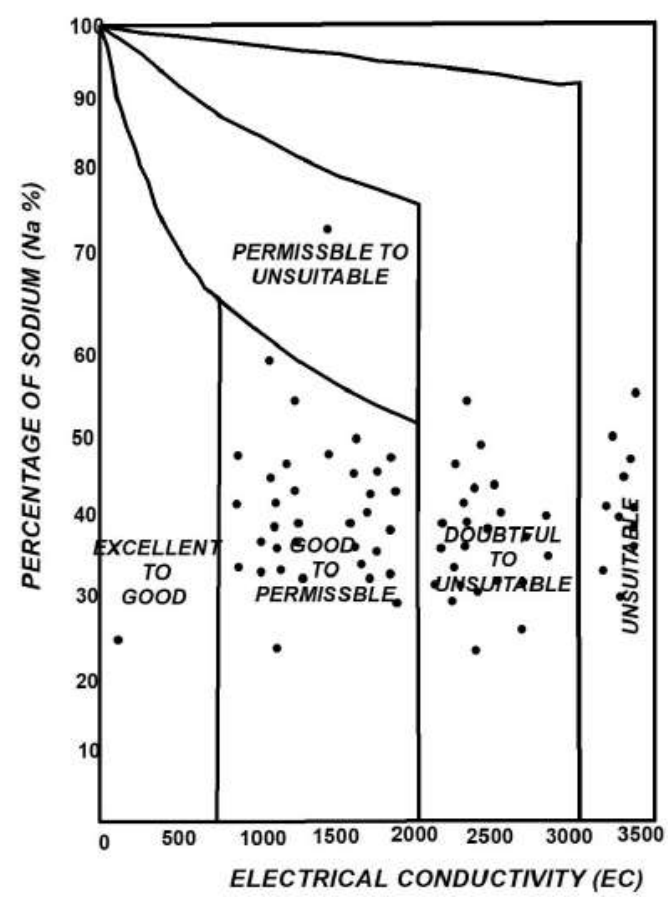

Fig.6. Wilcox diagram of the Vasishta sub- basin

Gibb's diagram. Gibbs diagram is mainly used to begin the affiliation of groundwater alignment and aquifer lithological characters. There are three domain fields, viz. precipitation dominance, evaporation dominance and rock-water interaction dominance domains in the Gibbs diagram (Gibbs, 1970). The maximum number of groundwater samples fall within the rock-water interaction domain and evaporation domain. The rock-water interaction domain clearly shows that the groundwater chemistry is controlled by aquifer materials. Gibbs diagram is presented in Fig. 7(a), (b)

Gibb's ratio for cations $=\mathrm{Na}+\mathrm{K} / \mathrm{Na}+\mathrm{K}+\mathrm{Ca}$

Gibb's ratio for anions $=\mathrm{Cl} / \mathrm{Cl}+\mathrm{HCO}_{3}$

All values of ion concentration are stated in meq/l. 


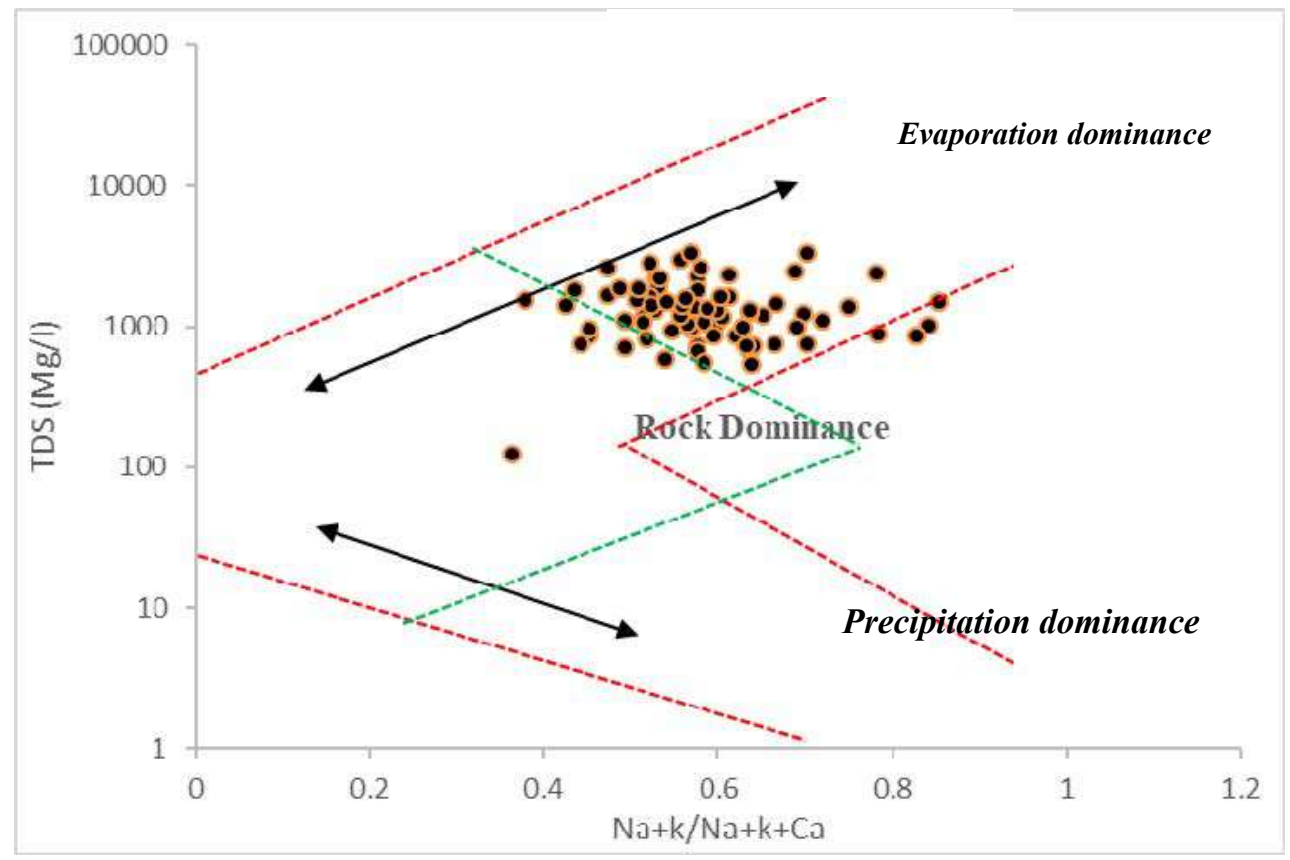

Fig.7. (a) Groundwater and rock interaction mechanism of Gibb's plot -cations

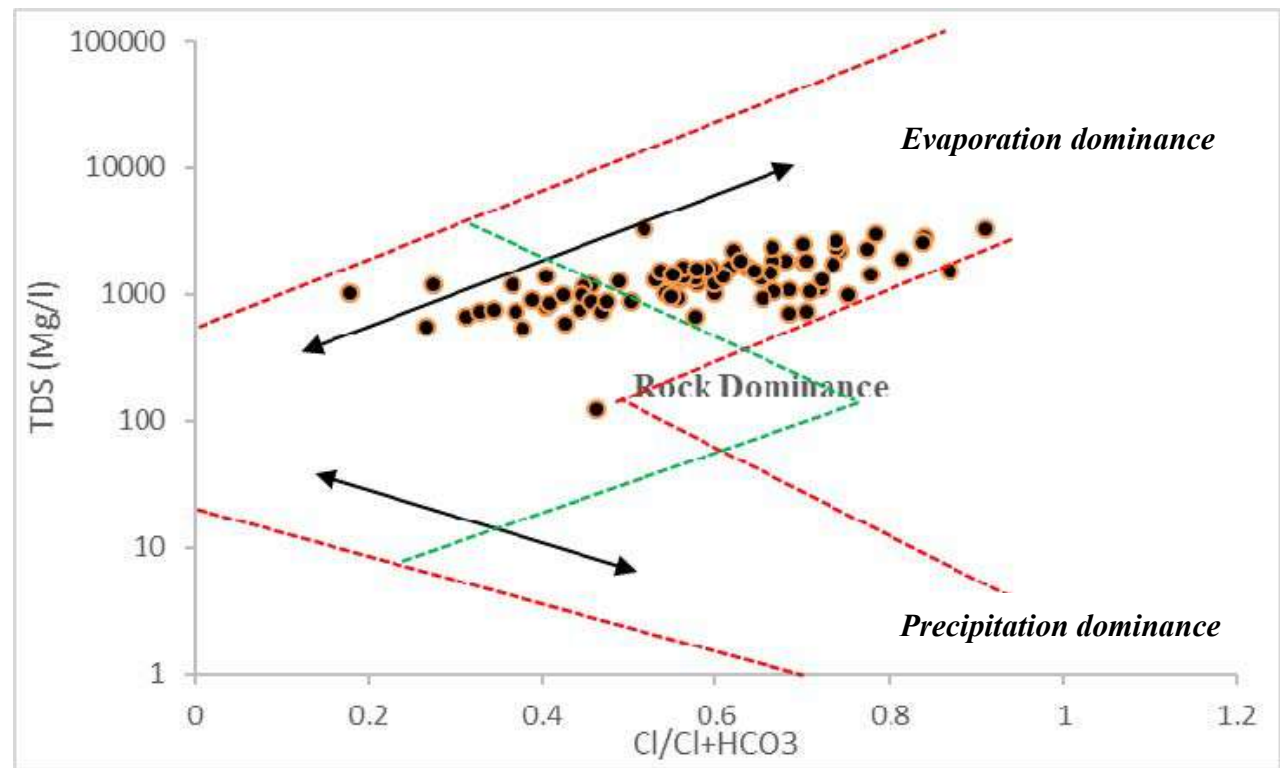

Fig.7. (b) Groundwater and rock interaction mechanism of Gibb's plot -anions

Results of the Correlation Matrix.The correlation analysis matrix involving statistical calculations was devised by Pearson (1896). It is commonly used to examine the degree of correlation between the different chemical parameters which affect the quality of groundwater. It is a simple measure to exhibit how well one variable predicts the other (Kurumbein and Greybill (1965).The Pearson correlation matrices (Swan and Sandilands 1995) are used to find the relationships between two or more variables. Coefficients $(r=>0.7)$ are considered to be strongly correlated where (r) values between 0.5 and 0.7 show moderated correlation at a significance level $p=0.05$ while $r<0.3$ is weak. It also illustrates that $\mathrm{EC}$ and TDS show high positive correlation with $\mathrm{Cl}, \mathrm{SO}_{4}, \mathrm{HCO}_{3}, \mathrm{Ca}, \mathrm{Cl}$ show very high positive correlation with $\mathrm{Ca}(\mathrm{r}=0.817)$. Good correlation is exhibited between $\mathrm{EC}$ and TDS Cl, $\mathrm{SO}_{4}$. $\mathrm{Cl}$ exhibits good correlation with $\mathrm{Mg}$ and $\mathrm{Ca}(0.817)$, (0.751) indicating leaching of secondary salts. TDS and EC showed strong correlation with $\mathrm{Cl}, \mathrm{SO}_{4}$ moderate correlation with $\mathrm{Ca}, \mathrm{Mg}, \mathrm{K}, \mathrm{F}$ and Hardness indicating that most of the ions are involved in physicochemical reactions such as oxidation reduction and ion exchange and also indicating that they are from the same source Subba Rao, (2002). Difference in variation of major cations and anions correlation is shown in Table 5. 


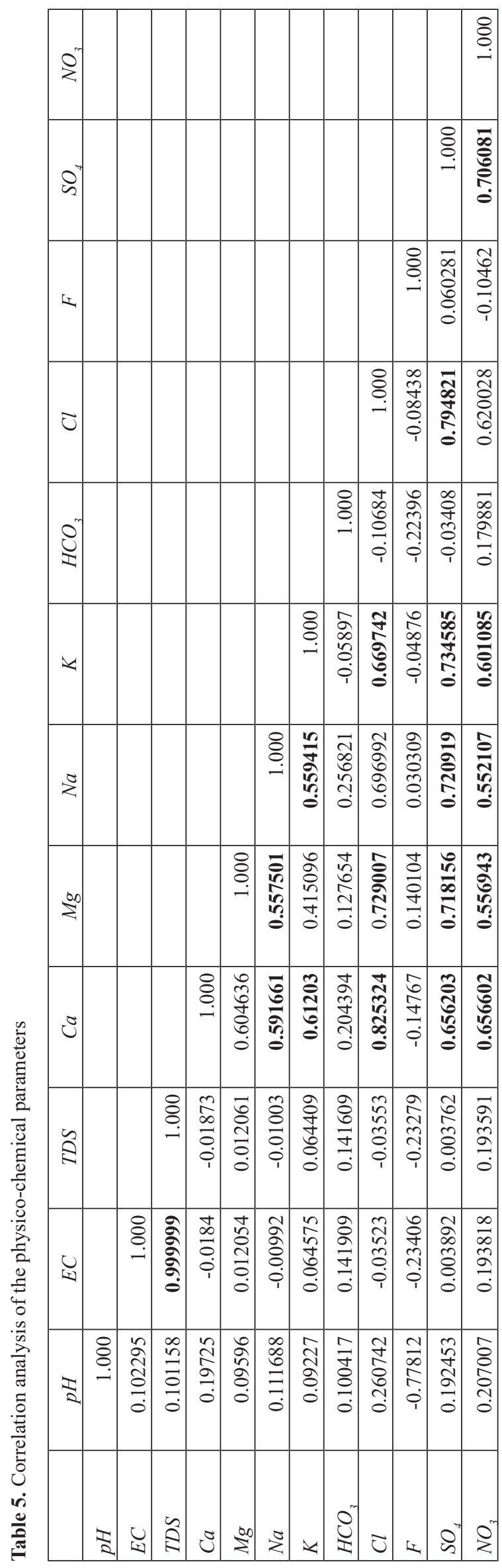

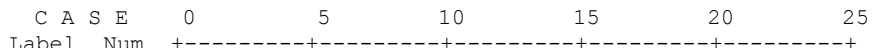

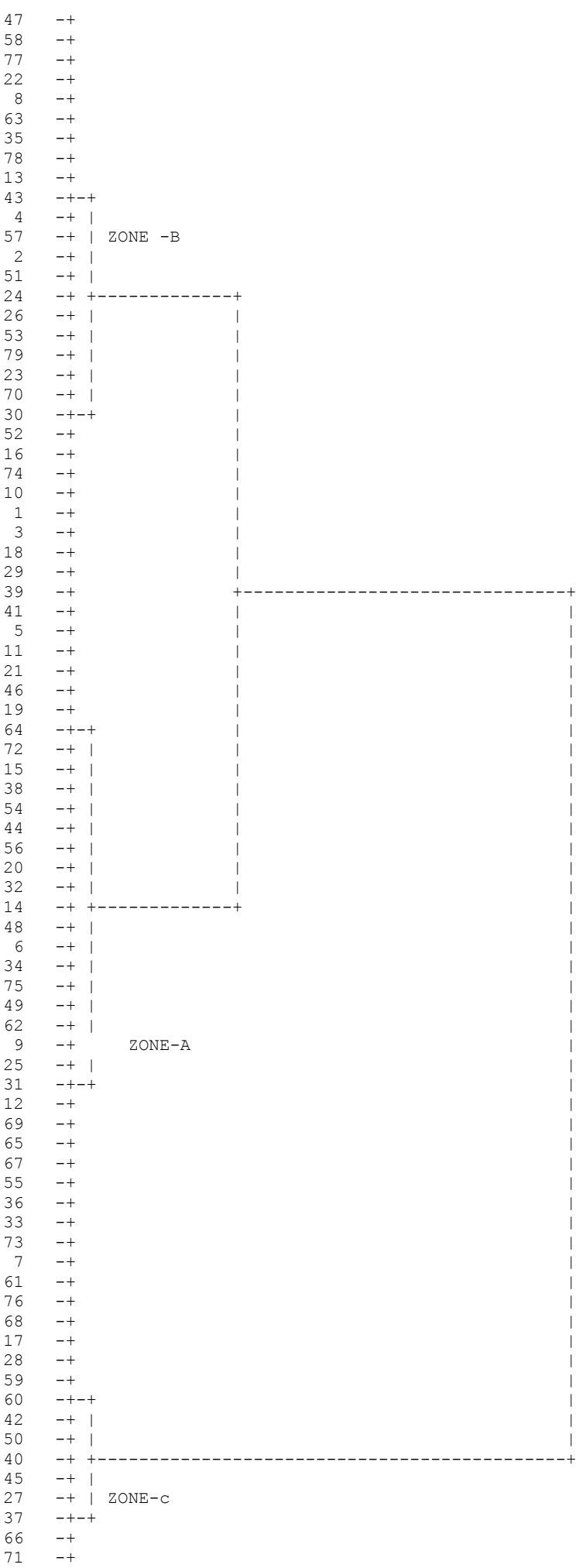

Fig.8. Cluster analysis in the dendrogram

Zone A grouped with the following groundwater samples (43, 4, 57, $2,51,24,26,53,79,23)$, Zone-B $(64,72,15,38,54,44,56,20$, $32,14,48,6,34,75,49,62,9,25,31)$ and one $C(60,42,50,0,45,27,37,66,71)$. TDS seems to be a major influencing factor in the following the order of dominance ; Zone $\mathrm{C}>$ Zone $\mathrm{B}>$ Zone $\mathrm{A}$. The zone A comprises samples $(32,54,74,55,66,9,8,64,72,52,53,28,10,31,35,5)$. The result is presented as a dendrogram shown in Figure.8. 


\section{Cluster analyses.}

Cluster analysis is a method for grouping individuals or objects according to their distinct characters. This method is used to group the groundwater chemical data. Each cluster indicates a particular groundwater character similarity. Clustering groundwater samples based on their similarity is known as Q-mode type clustering method. For the present study Q-mode clustering has been attempted to group the samples in terms of chemical characteristics. Ward's linkage uses the Pearson correlation method to produce the most distinctive groups where each member within the group is more similar to its fellow member than outside groups. All the 14 hydro chemical variables such as Electrical Conductivity (EC), Total Dissolved Solids (TDS), $\mathrm{P}^{\mathrm{H}}, \mathrm{Ca}, \mathrm{Mg}, \mathrm{Na}, \mathrm{K}, \mathrm{Cl}, \mathrm{SO}_{4}, \mathrm{NO}_{3}, \mathrm{HCO}_{3}$ and $\mathrm{F}$ were utilized in this analysis.

\section{Conclusions.}

The sub- basin is mainly comprised of Archean crystalline rocks such as gneisses, charnockite, pyroxinite, amphibole granulite and myolinite. Groundwater chemistry in the sub- basin is highly variable in nature. Groundwater occurs and movements in the sub basin are mainly in the weathered rocks, fissures, fractures and joints. The TDS values varied from 124 to $3335 \mathrm{mg} / 1$. TDS depends upon the groundwater interaction with different aquifer materials, and anthropogenic activities such as application of fertilizer, domestic sewage, and industrial effluent. The groundwater ionic concentration sequences are $\mathrm{Ca}>\mathrm{K}$ $>\mathrm{Mg}>\mathrm{Na}$ and $\mathrm{CO}_{3}>\mathrm{Cl}>\mathrm{SO}_{4}>\mathrm{HCO}_{3}>\mathrm{NO}_{3}$. Groundwater categories are fresh to brackish in nature, $\mathrm{Ca}$ and $\mathrm{Mg}$ are mostly within the allowable category, $\mathrm{NO}_{3}$ and $\mathrm{SO}_{4}$ are also within the allowable limit for domestic purposes, The dominant water quality index falls into

\section{References}

APHA, 1995.Standard methods for the examination of water and wastewater (19th edn). Am Pub Heal Ass, Washington, DC

Arulbalaji, P., and Gurugnanam, B. 2017. Groundwater quality assessment using geospatial and statistical tools in Salem District, Tamil Nadu, India Appl Water Sci 7:2737-2751 DOI 10.1007/s13201-016-0501-5

Baride, M, V., Patil S, N., Golekar, R, B., 2014. Groundwater geochemistry of shallow and deep aquifers from Jalgaon district, northern Maharashtra (India) International Journal of Advanced Geosciences, International Journal of Advanced Geosciences, 2 (2) 97-104

Bernard. J and Valla. P., 1991. Groundwater Exploration in fissured media with electrical and VLF methods. Geoexploration, v.27, 81-91

Biswal, TK., Thirukumaran, V., Ratre, K., Bandyapadhaya, K., Sundaralingam, K,, Mondal, AK., 2010. A study of the excellent to good categories based on WHO and BIS standards. According to Piper's trilinear diagram the groundwater facies are $\mathrm{Ca}-\mathrm{Mg}$ and $\mathrm{SO} 4$ type.In Wilcox's diagram it is clearly shown that most of the groundwater samples are suitable for irrigation purposes, however $3.79 \%$ of groundwater samples (from the villages Iddaiyapatti, Vellaiyur and Thiruvalanthurai) are not suitable for irrigation purposes, which may be due to geogenic and anthoropogenic activities. In Gibb's diagram it is clearly revealed that groundwater chemistry is mainly controlled by rock water interaction domain and evaporation domain. In the hydrochemical correlation matrix, high positive correlation is exhibited between EC-TDS ( $\mathrm{r}=0.9), \mathrm{Ca}-\mathrm{Cl}(\mathrm{r}=0.82)$, and moderate correlation between $\mathrm{Na}-\mathrm{Cl}, \mathrm{K}-\mathrm{Ca}, \mathrm{NO} 3-\mathrm{Ca}, \mathrm{Na}-\mathrm{Mg}$, $\mathrm{Cl}-\mathrm{Mg}$, SO4-Mg, SO4-Cl, NO3-SO4, with correlation value of 0.5 to 0.7 , weak correlation exists between Ca-EC $(r=-0.0184), F-K(r=-0.04)$. The correlation results projected in the dendrogram show that three groups were classified based on visual interpretation the dendrogram. Total dissolved solids seems to be a major influencing factor in the following order of dominance; Zone $\mathrm{C}>$ Zone $\mathrm{B}>$ Zone $\mathrm{A}$.

\section{Acknowledgements.}

The first author is highly thankful to DST, Government of India, Department of Science and Technology for their financial support in the form of INSPIRE Fellowship to carry out this research work in the DST-FIST sponsored Department of Geology, Periyar University, Salem, Tamil Nadu. I convey my deep, sincere and gratitude to my mentor Prof. Dr.S.Venkateswaran Professor and Head, for giving opportunity for carry out this research. We also thank the anonymous reviewers and editors for their constructive comments.

mylonites from parts of the Salem- Attur Shear Zone (Tamil Nadu) and its tectonic implications. J GeoSoc India 75:128-136

Gibbs, RJ., 1970. Mechanism controlling world water chemistry Science 170:795-840

Giuseppe Sappa, Sibel Ergul, Flavia Ferranti, 2014. Water quality assessment of carbonate aquifers in southern Latium region, Central Italy: a case study for irrigation and drinking purposes, Appl Water Sci 4:115-128 DOI 10.1007/s13201-013-0135-9

Ketata, M., Gueddari, M. and Bouhlila, R. 2012. Use of geographical information system water quality index to asses groundwater quality in El khairat deep aquifer (Enfidha, Central east Tunisia).Arabian Jour. Geosci.v.5(6), 1379-1390 
Krumbein, W. C., and Graybill, F.A., 1965.An Introduction to Statistical Models in Geology. By xi +475 pp., with figs. MaGraw-Hill, Volume 103, Issue 4

Maheswaran, G., and Elangovan, K., 2014. Groundwater Quality Evaluation in Salem District, Tamil Nadu, Based on Water Quality Index Nature Envi and Pollu Tec An Inter Quarterly Sci Jour Vol. 13, 3 pp. 547-552

Mahvi A.H., Nouri, J. A., Babaei A and Nabizadeh, R., 2005. Agricultural activities impact on groundwater nitrate pollution Int. J. Environ. Sci. Tech.Vol. 2, 1, 41-47, Springer

Marouane, B., Belhsain, K., Jahdi, M. E., Hajjaji, S., Dahchour, A., Dousset, and S., Satrallah A.,2014. Impact of agricultural practices on groundwater quality: Case of Gharb region-Morocco, J. Mater. Environ. Sci. 5 (S1) 2151-2155

Masoud Ei and Al-Ahmadi,2013. Hydrochemical characterization of groundwater in wadi Sayyah, Western Saudi Arabia, Appl Water Sci 3:721-732 DOI 10.1007/ s13201-013-0118-X

Nag. S.K., and Poulomi Ghosh, 2011.Groundwater quality and its suitability to agriculture - GIS based case study of Chhatna block, Bankura district, West Bengal, India, International Journal of Environmental Sciences Volume 1, 7, 1770-1784.

Oke, S A., and aladejana, J, A. 2012.Assessment of shallow groundwater quality for irrigation purposes in basement complex terrain of southwestern Nigeria, hydrology for disaster management special publication of the Nigerian association of hydrological sciences, southeastern Tunisia) Environ Earth Sci 71:3387-3421 DOI 10.1007/s12665-013-2729-9,

Paralta E., Feranades, R., Carreira, and P, Riberiro, L.,2005. Assessing the impacts of agriculture on groundwater quality using nitrogen isotopes - preliminary results on the "Gabbros of Beja" aquifer system (South Portugal) 2nd workshop of the Iberian regional working group on hard rock hydrogeology, 18-21 May 2005, Evora, Portugal,14pp.

Pearson, K. 1896. Mathematical contributions to the theory of evolution, III: Regression, heredity and panmixia. Philos. Trans. Roy. Soc. London (, A) 187253-318. Cambridge Univ. Press. Abstract in Proc. Roy. Soc. London (1897) 62 173-176.

Piper, A. M., 1944. A graphical procedure in the geochemical interpretation of water analysis. Am Geophys Union Trans 25:914-928

Poongodi, R., and Venkateswaran, S., 2018. Prioritization of the micro-watersheds through morphometric analysis in the Vasishta Sub Basin of the Vellar River, Tamil Nadu using ASTER Digital Elevation Model(DEM) data, Data in Brief (20) 1353-1359 Elsevier

Ragunath, H. M. 1987. Geochemical survey and water quality. Groundwater. Wiley Eastern Limited, New Delhi, pp.343-347.

Rodriguez-Estrella, T., 2012. The problems of overexploitation of aquifers in semi-arid areas: the Murcia Region and the Segura Basin (South-east Spain) case Hydrol. Earth Syst. Sci. Discuss., 9, 5729-5756,
Sarath Prasanth, S. V., Magesh, N. S., Jitheshlal, K. V., Chandrasekar, N., Gangadhar, K., 2012. Evaluation of groundwater quality and its suitability for drinking and agricultural use in the coastal stretch of Alappuzha District, Kerala, India, Appl Water Sci 2:165-175 DOI 10.1007/s13201-012-0042-5

Saravanan, K., Srinivasamoorthy, S., Gopinath R., Prakash, C, Suma S.,2016. Investigation of hydrogeochemical processes and groundwater quality in Upper Vellar sub- basin Tamilnadu, India, Arab J Geosci 9: 372 DOI 10.1007/s12517-016-2369

Satheesh Kumar, V., Amarender Ratnakar Dhakate, B., Sankaran, S., Raj Kumar, K., 2018. Assessment of groundwater quality for drinking and irrigation use in shallow hard rock aquifer of Pudunagaram, Palakkad District Kerala, Appl Water Sci DOI 10.1007/s13201014-0214-6

Shah, S. M., and Mistry N.J., 2013. Groundwater Quality Assessment for Irrigation Use in Vadodara District, Gujarat, India, World Academy of Science, Engineering and Technology Vol:7 2013-07-23

Sharif, MU., Davis, RK., Steele, KF., Kim, B., Kresse TM., Fazio, JA., 2008. Inverse geochemical modeling of groundwater evolution with emphasis on arsenic in the Mississippi River Valley alluvial aquifer, Arkansas (USA. J of Hydrology. https://doi.org/10.1016/j. jhydr ol. 2007.11 .027

Sreedevi PD, 2002. A case study on changes in quality of groundwater with seasonal fluctuations of Pageru river basin, Cuddapah District, Andhra Pradesh, India. J Environ Geol 42:414-423.

Srinivas, Y., Hudson Oliver, D., Stanley Raj A., Chandrasekar, N., 2013. Evaluation of groundwater quality in and around Nagercoil town, Tamilnadu, India: an integrated geochemical and GIS approach, Appl Water Sci 3:631651 DOI 10.1007/s13201-013-0109-y

Srinivasamoorthy K, Nandha Kumar C, Vijayaraghavan K, Vasanthavigar M, Rajiv Gandhi R, Chidambaram S, Anandhan P, Manivannan R, Vasudevan S., 2011. Groundwater quality assessment from a hard rock terrain, Salem district of Tamilnadu, India. Arab J Geo Sci 4:91-102.

Srinivasamoorthy, K., Nanthakumar, C., Vasanthavigar, M., Vijayaraghavan, K., Rajivgandhi, R., Chidambaram, S., Anandhan, P., Manivannan, R., Vasudevan, S., 2009. Groundwater quality assessment from a hard rock terrain, Salem district of Tamilnadu, India. Arab J Geosci. https://doi.org/10.1007/s1251 7-009-0076

Subba Rao, N., Vidyasagar, G., Surya Rao, P., Bhanumurthy, P., 2014. Chemistry and quality of groundwater in a coastal region of Andhra Pradesh, India, Appl Water Sci DOI 10.1007/s13201-014-0244-0

Subba Rao, S., 2002. Geochemistry of groundwater in parts of Guntur district, Aandra Pradesh, India Envir Geology 41:552-562

Subramani T, Rajmohan N, Elango L (2010) Groundwater geochemistry and identification of hydrogeochemical processes in a hard rock region, Southern India. Environ Monit Assess: 162:123-137. 
Swan A.R. H., and Sandilands, M., 1995. "Introduction to Geological Data Analysis," Blackwell, Oxford,

Tamma Rao G., Gurunadha Rao V, S., and Ranganathan K., 2013. Hydrogeochemistry and groundwater quality assessment of Ranipet industrial area, Tamil Nadu, India, J. Earth Syst. Sci. 122, No. 3, June, 855-867

Todd DK (1980) Groundwater Hydrology, 2nd edn. Wiley, New York, 535 p.

Uday Veer Singh, Amar Abhishek Kunwar, P., Singh Ratnakar, Dhakate Netra Pal Singh, 2014.Groundwater quality appraisal and its hydrochemical characterization in Ghaziabad (a region of indo-gangetic plain), Uttar Pradesh, India, Appl Water Sci 4:145-157, DOI 10.1007/ s13201-013-0137-7

Vasanthavigar, M., Srinivasamoorthy, K., Vijayaragavan, K., Rajiv Ganthi, R., Chidambaram, S., Anandhan, P., Manivannan, R., and Vasudevan, S., 2010. Application of water quality for groundwater quality assessment: Thirumanimuttar Sub basin, Tamil Nadu, India. Environ Monit Assess 171(1-4):595-609

Veena Chaudhary, and Satheeshkumar, S., 2018. Assessment of groundwater quality for drinking and irrigation purposes in arid areas of Rajasthan, India Applied
Water Science 8:218 https://doi.org/10.1007/s13201018-0865-9

Venkateswaran, S., 2010. Hydrogeology and Geochemical characterisation of groundwater with special emphasis on agricultural development in Vaniyar sub basin, Ponnaiyar river, Tamil Nadu., International Journal of Recent Scientific Research vol. 1, issue, 12, 213-221

Vijayakumar, V S., Krishnakumar, S., and Vasudevan, 2016. An Environmental Quality Assessment on Groundwater Geochemistry in Western Part of Perambalur District, Tamilnadu, India, Journal of Environmental Science and Pollution Research 2(1) 54-56

WHO, 2011. WHO Guidelines for Drinking-water Quality, fourth ed. World Health Organization (Amsterdam), 228(1-2), 37-47.

Wilcox's, LV., 1955. Classification and use of irrigation waters. USDA, Circular 969, Washington, DC

William Bajjali, Kheir Al-Hadidi, and Ma'mmon Ismail, 2017. Water quality and Geochemistry evaluation of groundwater upstream and downstream of the Khirbet Al-Samra wastewater treatment plant/Jordan, Appl Water Sci 7:53-69 DOI 10.1007/s13201-014-0263-X 